\title{
Comparison of the functional results of radial head resection and prosthesis for irreparable mason type-III fracture
}

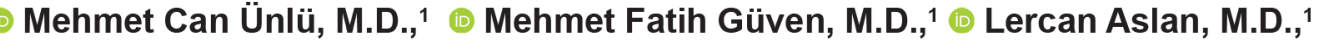 \\ D Önder Aydıngöz, M.D., ${ }^{1}$ - Mustafa Gökhan Bilgili, M.D., ${ }^{2} \odot$ Alkan Bayrak, M.D., ${ }^{2}$ \\ (1) Muharrem Babacan, M.D.,' [i] Gökhan Kaynak, M.D.,' 이 Hüseyin Botanlıoğlu, M.D. ${ }^{1}$
}

1'Department of Orthopedics and Traumatology, İstanbul University Cerrahpaşa Faculty of Medicine, İstanbul-Turkey

${ }^{2}$ Department of Orthopaedics and Traumatology, Bakırköy Dr. Sadi Konuk Training and Research Hospital, İstanbul-Turkey

\begin{abstract}
BACKGROUND: The radial head is essential for the rotational stability of the forearm and resistance to valgus stress. Radial head fractures are the most common elbow fracture in adults. Various treatment options are available, depending on the fracture severity. However, the treatment of Type-III fractures is controversial. The aim of this study was to evaluate functional results in patients with irreparable Mason Type-III radial head fractures treated with radial head resection or prosthesis.
\end{abstract}

METHODS: Fourteen irreparable Mason Type-III radial head fracture patients treated with radial head resection ( $n=7$ ) or radial head prosthesis $(n=7)$ were evaluated in this multicenter, retrospective study. Disabilities of the Arm, Shoulder and Hand (DASH) and Mayo Elbow and Wrist scores were used to determine clinical outcomes. A hydraulic hand dynamometer was used to measure grip strength on the operated and unoperated sides to avoid potential bias. Measurements were made three times for each extremity, and the mean value was recorded. Grip strength was calculated as a percentage of the strength of the unoperated side.

RESULTS: Functional outcomes for resection and prosthesis patients were the following: mean DASH scores, 25.8 and I7.2; mean Mayo Elbow scores, 74 and 84.I; mean Mayo Wrist scores, 84 and 92.5; and maximum grip strengths, $48.8 \%$ and $77.8 \%$, respectively. The range of motion of the respective resection and prosthesis groups were as follows: flexion, $112.14^{\circ}$ and $104.29^{\circ}$; extension, $-10.00^{\circ}$ and $-25.00^{\circ}$; pronation, $70.00^{\circ}$ and $47.86^{\circ}$; and supination, $70.00^{\circ}$ and $52.14^{\circ}$.

CONCLUSION: Although range of motion was restricted in the radial head resection group, functional results and grip strength were superior in patients treated with a radial head prosthesis. These results support the radial head prosthesis as a superior treatment modality for patients with irreparable Mason Type-III radial head fractures with respect to patient satisfaction and functional outcomes.

Keywords: Arthroplasty; fracture; prosthesis; radial head; resection.

\section{INTRODUCTION}

Radial head fracture is the most frequently diagnosed fracture of the elbow in adults. ${ }^{[1,2]}$ The radial head is crucial for elbow biomechanics and, in particular, resistance to valgus stress and the rotational stability of the forearm. ${ }^{[3,4]}$ Therefore, restoration of elbow biomechanics is essential for acceptable func- tional results in radial head fractures. Various treatment options are available, depending on fracture severity. ${ }^{[5,6]}$ Although biological treatment modalities, such as conservative methods and open reduction and internal fixation, are first-choice treatments, ${ }^{[7]}$ especially for Mason Type-III fractures, the optimum treatment method remains controversial. ${ }^{[5,6]}$ Results of radial head resection $(\mathrm{RHR})^{[8,9]}$ and radial head prosthesis

Cite this article as: Ünlü MC, Botanlığlu H, Güven MF, Arslan L, Aydıngöz Ö, Bilgili MG, et al. Comparison of the functional results of radial head resection and prosthesis for irreparable mason type-III fracture. Ulus Travma Acil Cerrahi Derg 2018;24:359-363.

Address for correspondence: Hüseyin Botanlıŏlu, M.D.

İstanbul Üniversitesi Cerrahpaşa Tıp Fakültesi, Ortopedi ve Travmatoloji Anabilim Dalı, Turkey

Tel: +90 212 - 4/4 3000 E-mail: huseyinbotanlioglu@gmail.com

Ulus Travma Acil Cerrahi Derg 2018;24(4):359-363 DOI: 10.5505/tjtes.2017.97682 Submitted: 08.08.2017 Accepted: 21.09.2017 Online: 23.10.2017

Copyright 2018 Turkish Association of Trauma and Emergency Surgery 
$(\mathrm{RHP})^{[10-12]}$ for radial head fractures have been presented in the literature, but relevant data remain limited. The main objective of this study was to compare these two treatment modalities in terms of the clinical outcomes and grip strength of patients with irreparable Mason Type-III radial head fractures.

\section{MATERIALS AND METHODS}

In this retrospective comparative study, patients with an isolated radial head fracture who were surgically treated with either RHR or RHP in two different clinics and by two different surgeons between 2008 and 2013 were evaluated. Patients with RHR and RHP were evaluated clinically and radiographically. Fractures were classified according to the Mason classification system, ${ }^{[13]}$ and only Type-III fractures were included (Fig. I). Patients with additional bone damage, neurological deficit, or instability at the time of diagnosis or with prior upper-extremity trauma anamnesis were excluded. Fourteen patients matched the criteria and were divided into two groups: those in Group I were treated with RHR, and those in Group II were treated with RHP. Interposition arthroplasty was not performed on patients in Group I. Each group consisted of seven (five males and two females in Group I, four males and three females in Group II) patients. In Group I, the mean age at the time of the operation was $\mathbf{4 2 . 5}$ years. Two patients were left hand dominant and five were left hand dominant. The right elbow was affected in two patients, and the left elbow was affected in five patients, with the dominant limb being affected in two patients. The mean follow-up duration was 31.1 months. In Group II, the mean age at the time of the operation was 49 years. One patient was left hand dominant and six were left hand dominant. The right elbow was affected in three patients, and the left elbow was affected in four patients, with the dominant limb being affected in three patients. The mean follow-up duration was $\mathbf{2 8 . 2}$ months. All patients were initially immobilized in a long-arm splint at $90^{\circ}$ of elbow flexion with neutral rotation during the postoperative period. In all cases, motion was initiated within 7-10 days.

All surgical procedures were performed by two different surgeons, and all patients were evaluated clinically and ra-
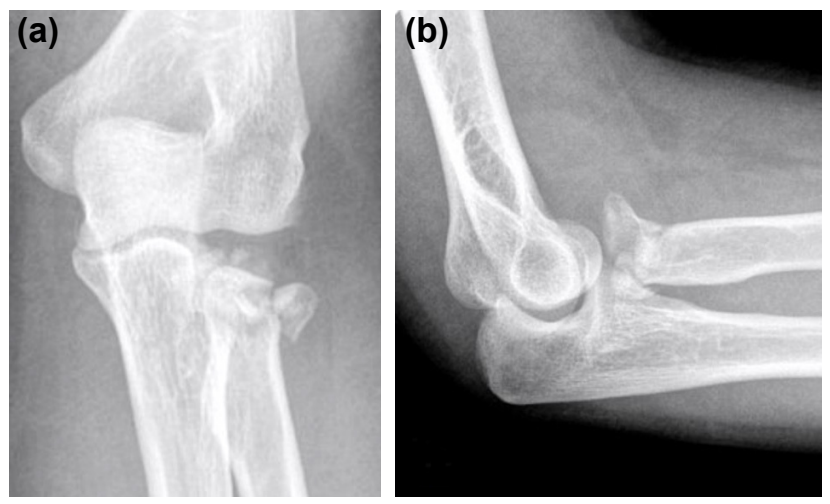

Figure 1. Anteroposterior (a) and lateral (b) X-ray images of a patient with Mason Type-III radial head fracture. diographically at the end of the follow-up period. The range of motion of the elbow and forearm were measured using a goniometer, and the values were compared with those of the uninjured side. The Disabilities of the Arm, Shoulder and Hand (DASH), ${ }^{[14]}$ Mayo Wrist, ${ }^{[15]}$ and Oxford Elbow ${ }^{[16]}$ scoring systems were used to evaluate the functional status. The maximum grip strength of each patient was assessed with the Jamar hydraulic hand dynamometer (JAMAR ${ }^{\circledR}$ Plus+ Digital Hand Dynamometer; Patterson Medical/Sammons Preston, Bolingbrook, IL, USA), which is recommended by the American Hand Therapist Society. ${ }^{[17]}$ For measurements, the patients were in a comfortable sitting position with the arm at abduction and neutral rotation, the elbow flexed at $90^{\circ}$, and the wrist in a neutral position. Grip strength was measured with the forearm in supination, pronation, and a neutral position; three measurements were taken for each position (Fig. 2). The mean value was determined, which was measured in pounds (lbf). ${ }^{[18]}$ Assessment was also performed on the unaffected side using the same method. An adjustment was made for right-handed patients in terms of their dominant hand. The difference between the dominant and nondominant sides was considered to be $10 \%$ for right-handed patients; for lefthanded patients, the difference in hand dominance was ignored. ${ }^{[19,20]}$ Anteroposterior and lateral $X$-rays were used for radiological assessment at the end of the follow-up period. Congruency of the elbow joint surface, proximal medial shift of the radius, and degenerative changes (subchondral sclerosis, joint space narrowing, etc.) were evaluated.

Statistical analysis was performed by the NCSS 2007 statistical software (Number Cruncher Statistical System, UT, USA). The Mann-Whitney U-Test, Fisher's exact test, and the Wilcoxon test were used for comparing groups, evaluating qualitative data, and comparing affected and unaffected sides as well as for descriptive statistics, including means and standard deviations. A p-value of $<0.05$ was considered to indicate statistical significance.

\section{RESULTS}

In Group I, the mean DASH, Oxford Elbow, and Mayo Wrist
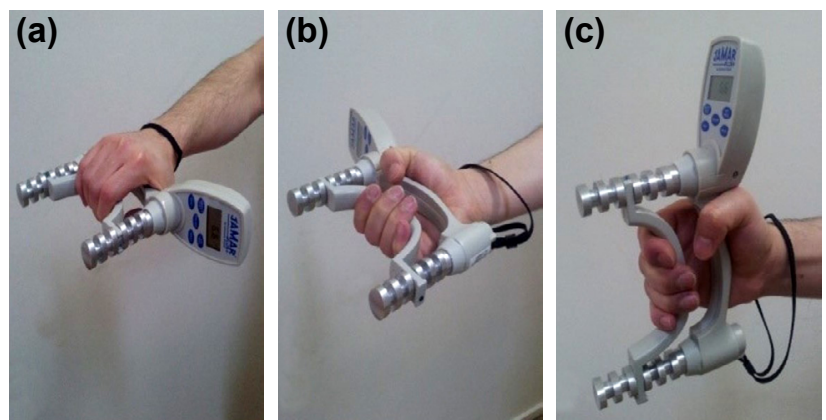

Figure 2. Hand grip strength of patients was measured with a hydraulic hand dynamometer (JAMAR ${ }^{\circledR}$ Plus + ) in pronation (a), supination (b), and a neutral position (c). Patients were placed in a relaxed sitting position with $90^{\circ}$ of elbow flexion. 

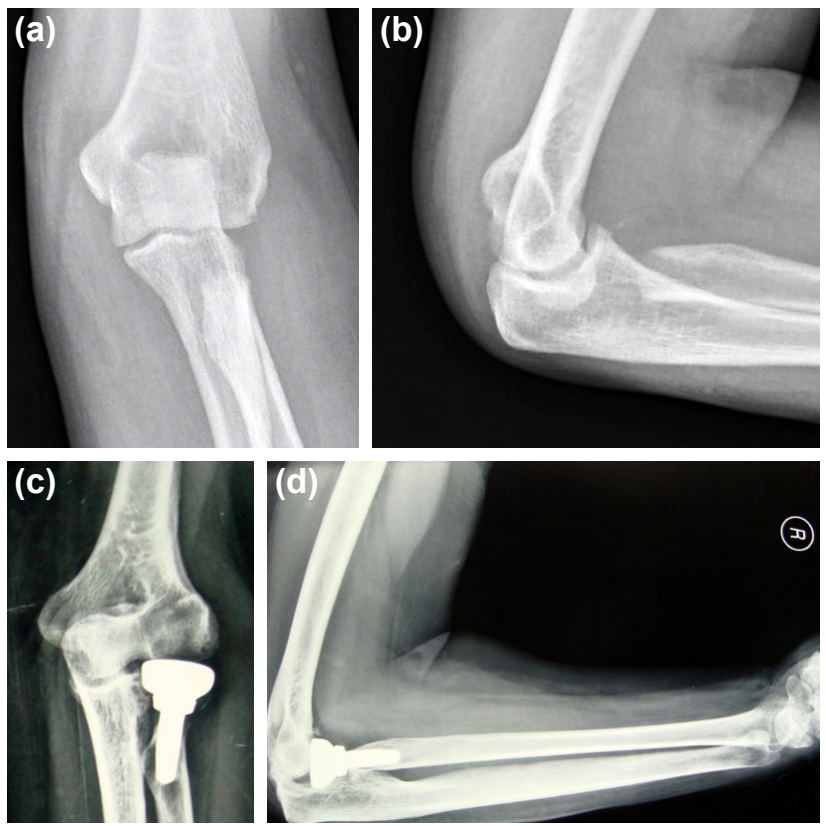

Figure 3. Postoperative X-ray images of patients treated with radial head resection $(\mathbf{a}, \mathbf{b})$ and radial head prosthesis $(\mathbf{c}, \mathbf{d})$. In patients treated with radial head resection, medial radial shift was observed in anteroposterior X-ray images.

scores were 25.84, 32.43, and 84.29, respectively (Table I). At the final examination, the mean values for flexion, extension, pronation, and supination were $112.14,-10.00,70.00$, and 70.00 , respectively, on the affected sides of patients treated with RHR (Table 2). In Group II, the mean DASH, Oxford Elbow, and Mayo Wrist scores were 19.91, 40.29, and 94.29, respectively. At the end of the follow-up period, the mean values for flexion, extension, pronation, and supination were 104.29, $-25.00,47.86$, and 52.14, respectively, on the affected sides of patients treated with RHP. No instability was detected on the last physical examination of each group.

Considering radiological assessment, proximal medial radial shift was observed in all patients treated with RHR (Figure 3). No sign of heterotopic ossification was observed in either group, and no signs of implant loosening were recorded in Group II. Subchondral sclerosis and joint space narrowing were identified in one patient in each group.

Comparing the two groups, the difference in terms of flexion and grip strength did not reach significance, but extension was restricted in Group II $(p=0.014)$. In addition, there were no significant differences between the unaffected sides of each group with respect to flexion and extension. Analysis between affected and unaffected sides showed that flexion and extension were negatively affected in both the groups $(p<0.05)$. Moreover, in Group I, grip strength was negatively affected in all positions; however, grip strength was decreased in only the neutral position in Group II (Table 2).

No wound infection, sepsis, or neurovascular compromise was observed in the study patients. Moreover, no postoper-
Table I. Demographic characteristics and functional results of our study including statistical analysis

\begin{tabular}{|c|c|c|c|}
\hline & RA group & RHP group & $\mathbf{p}$ \\
\hline Age (years) & 42.5 & 49 & 0.125 \\
\hline \multicolumn{4}{|l|}{ Gender } \\
\hline Male & 5 & 4 & 0.557 \\
\hline Female & 2 & 3 & \\
\hline \multicolumn{4}{|l|}{ Side } \\
\hline Left & 5 & 4 & 0.557 \\
\hline Right & 2 & 3 & \\
\hline Follow-up (months) & 31 & 28 & 0.222 \\
\hline DASH score & 25.8 & 19.9 & 0.798 \\
\hline Oxford Elbow score & 32 & 40 & 0.334 \\
\hline Mayo Wrist score & 84 & 94 & 0.209 \\
\hline
\end{tabular}

RA: Resection arthroplasty; RHP: Radial head prosthesis; p: P-value $<0.05$. No statistically significant difference between two groups in terms of functional results.

Table 2. Range of motion and hand grip strength results of our study including statistical analysis. Extension is significantly restricted in Group II. The difference between two groups in terms of grip strength is not statistically significant

\begin{tabular}{lccc}
\hline & RA (Group I) & RHP (Group 2) & p \\
\hline ROM flexion & & & \\
AS & $112.14 \pm 10.75$ & $104.29 \pm 5.35$ & 0.054 \\
NAS & $127.86 \pm 6.99$ & $127.86 \pm 6.99$ & I \\
P & 0.041 & 0.016 & \\
ROM extansion & & & \\
AS & $-10 \pm 8.66$ & $-25 \pm 9.57$ & 0.014 \\
NAS & $0 \pm .0$ & $0 \pm .0$ & 1 \\
P & 0.042 & 0.018 & \\
GS-neutral & & & \\
AS & $41.89 \pm 27.58$ & $58.19 \pm 16.72$ & 0.225 \\
NAS & $75.16 \pm 9.28$ & $70.66 \pm 15.31$ & 0.225 \\
P & 0.018 & 0.028 & \\
GS-pronation & & & \\
AS & $41.09 \pm 21.76$ & $52.36 \pm 13.77$ & 0.180 \\
NAS & $62.36 \pm 8.15$ & $62.14 \pm 17.33$ & 0.565 \\
P & 0.018 & 0.091 & \\
GS-supination & & & \\
AS & $44.41 \pm 24.87$ & $54.4 \pm 15.76$ & 0.277 \\
NAS & $70.49 \pm 6.41$ & $64.06 \pm 4.89$ & 0.064 \\
P & 0.018 & 0.176 & \\
\hline
\end{tabular}

RA: Resection arthroplasty, RHP: Radial head prosthesis; ROM: Range of motion; GS: Grip strength; AS: Affected side; NAS: Nonaffected side; p: p-value $<0.05$. 
ative ligamentous instability or posterior interosseous nerve injury was observed.

\section{DISCUSSION}

Biological methods are first-choice treatments for isolated Mason Type-III fractures but are considered controversial in the treatment of fractures with $\geq 3$ fragments. ${ }^{[2]]}$ A meta-analysis of the treatment of Mason Type-III fractures favored the outcomes of RHP over those of osteosynthesis. ${ }^{[22]}$ RHR and RHP are the preferred treatment choices for irreparable Mason Type-III fractures. ${ }^{[7,23]}$ However, conflicting results have been reported in the literature regarding both treatment modalities. Moreover, studies comparing the outcomes of RHR and RHP are limited.

In our study, loss of grip strength and motion were observed in patients treated with RHR, which was compatible with the literature. However, we did not encounter complications such as elbow instability, neuropathy, and proximal radioulnar synostosis because fractures with associated injuries were specifically excluded from our study. Our results are supported by a study conducted by Karlsson et al. ${ }^{[8]}$ that evaluated isolated comminuted radial head fractures; this study found that the mean range of motion deficit in the elbow was $5^{\circ}-10^{\circ}$. In addition, good to excellent results according to the Mayo Elbow Performance Index were reported by Antuña et al. ${ }^{[9]}$ in a review of 26 patients treated with primary radial head excision who were followed up for a minimum of 15 years. However, Swanson et al. ${ }^{[24]}$ presented a clear sequence of events when a loss of radiocapitellar contact resulted in lateral elbow instability, arthritis, loss of strength and motion, and ulnar nerve symptoms. In terms of RHR, it has been reported that $55 \%$ patients encountered restrictions in their daily life, and $36 \%$ experienced limitations at work. ${ }^{[25]}$ Herbertsson et al. ${ }^{[26]}$ suggested that, if the initial attempt to save the radial head caused unfavorable results, a delayed excision may be performed.

Radial head arthroplasty is indicated for the management of comminuted displaced radial head fractures when stable internal fixation is unachievable or in cases of instability following radial head excision, malunion, and nonunion. In our study, satisfactory functional and clinical results were achieved in patients treated with RHP with no signs of implant loosening or instability. These outcomes were supported by Harrington et al., ${ }^{[1]}$ who presented the results of the long-term followup of 20 patients treated with RHP; use of a prosthesis was advocated when the radial head could not be reconstructed to restore the stability of the elbow and forearm. Moreover, Zunkiewicz et al. ${ }^{[2]}$ reported the results of 29 patients with a mean follow-up period of 34 months. Satisfactory functional scores, with a Mayo Elbow Performance Index score of 92 and an acceptable level of complications, were noted. The outcomes of patients with acute traumatic elbow instability treated with RHP were presented in a study that included 27 patients. In that study, 22 patients had good or excellent results according to the Mayo Elbow Performance Index. Unlike our evaluation, complications including stem loosening, component failure, instability, infection, dislocation, and arthritis were reported. ${ }^{[27]}$ Another complication difference was reported by Flinkkilä et al.,"28] who reviewed the results of press-fit RHP in 37 patients with a mean follow-up of 50 months. One-third of their patients had early symptomatic loosening, which necessitated implant removal in nine patients. In addition, Lópiz et al. ${ }^{[10]}$ reported the mid-term follow-up of RHR and RHP patients. Their functional results were better for RHP; however, with a higher complication rate, a greater number of patients required revision surgeries, thus lowering their mean functional status. The longer followup duration and older patient age compared to our study may be one reason for the revision surgeries and may have contributed to the lower functional scores.

Hand grip strength is crucial for performing the activities of daily life and for good functional results. ${ }^{[29]}$ Research comparing the functional and grip strength results of RHP and RHR in the treatment of Mason Type-III radial head fractures is limited. In our study, the mean functional score and grip strength results were superior in patients treated with RHP, but this difference did not reach significance, which may be attributable to our small number of patients. Analysis showed that extension was significantly restricted in the RHP group. Most importantly, in Group I, decreased grip strength was observed in all positions of the forearm. However, this decrease was limited to only the neutral position in Group II.

The limitations of our study are its retrospective design, including patients treated at two different clinics by two different surgeons, and its small sample size. Studies with more patients and a longer follow-up period are necessary for more conclusive results.

\section{Conclusion}

Patients with irreparable Mason Type-III radial head fractures who require excellent hand grip strength are excellent candidates for RHP. However, RHR is easy to perform and is a good treatment choice for patients with isolated Mason Type-III radial head fractures who wish to reclaim their ability to perform the activities of daily life at the cost of grip strength.

\section{Conflict of interest: None declared.}

\section{REFERENCES}

1. Rosenblatt Y, Athwal GS, Faber KJ. Current recommendations for the treatment of radial head fractures. Orthop Clin North Am 2008;39:173-85.

2. Pike JM, Athwal GS, Faber KJ, King GJ. Radial head fractures-an update. J Hand Surg Am 2009;34:557-65. [CrossRef]

3. Charalambous CP, Stanley JK, Mills SP, Hayton MJ, Hearnden A, Trail I, et al. Comminuted radial head fractures: aspects of current management. J Shoulder Elbow Surg 2011;20:996-1007. [CrossRef]

4. Ring D. Radial head fracture: open reduction-internal fixation or pros- 
thetic replacement. J Shoulder Elbow Surg 2011;20:S107-12. [CrossRef]

5. Ruchelsman DE, Christoforou D, Jupiter JB. Fractures of the radial head and neck. J Bone Joint Surg Am 2013;95:469-78. [CrossRef]

6. Lapner M, King GJ. Radial head fractures. J Bone Joint Surg Am 2013;95:1136-43.

7. Zarattini G, Galli S, Marchese M, Mascio LD, Pazzaglia UE. The surgical treatment of isolated mason type 2 fractures of the radial head in adults: comparison between radial head resection and open reduction and internal fixation. J Orthop Trauma 2012;26:229-35. [CrossRef]

8. Karlsson MK, Herbertsson P, Nordqvist A, Hasserius R, Besjakov J, Josefsson PO. Long-term outcome of displaced radial neck fractures in adulthood: 16-21 year follow-up of 5 patients treated with radial head excision. Acta Orthop 2009;80:368-70. [CrossRef]

9. Antuña SA, Sánchez-Márquez JM, Barco R. Long-term results of radial head resection following isolated radial head fractures in patients younger than forty years old. J Bone Joint Surg Am 2010;92:558-66. [CrossRef]

10. Lópiz Y, González A, García-Fernández C, García-Coiradas J, Marco F. Comminuted fractures of the radial head: resection or prosthesis? Injury 2016 Sep;47 Suppl 3:S29-34. [CrossRef]

11. Harrington IJ, Sekyi-Otu A, Barrington TW, Evans DC, Tuli V. The functional outcome with metallic radial head implants in the treatment of unstable elbow fractures: a long-term review. J Trauma 2001;50:46-52.

12. Zunkiewicz MR, Clemente JS, Miller MC, Baratz ME, Wysocki RW, Cohen MS. Radial head replacement with a bipolar system: a minimum 2-year follow-up. J Shoulder Elbow Surg 2012;21:98-104. [CrossRef]

13. Mason ML. Some observations on fractures of the head of the radius with a review of one hundred cases. Br J Surg 1954;42:123-32. [CrossRef]

14. Hudak PL, Amadio PC, Bombardier C. Development of an upper extremity outcome measure: the DASH (disabilities of the arm, shoulder and hand) [corrected]. The Upper Extremity Collaborative Group (UECG). Am J Ind Med 1996;29:602-8. [CrossRef]

15. MacDermid JC, Turgeon T, Richards RS, Beadle M, Roth JH. Patient rating of wrist pain and disability: a reliable and valid measurement tool. J Orthop Trauma 1998;12:577-86. [CrossRef]

16. The B, Reininga IH, El Moumni M, Eygendaal D. Elbow-specific clinical rating systems: extent of established validity, reliability, and responsive- ness. J Shoulder Elbow Surg 2013;22:1380-94. [CrossRef]

17. Mathiowetz V, Weber K, Volland G, Kashman N. Reliability and validity of grip and pinch strength evaluations. J Hand Surg Am 1984;9:222-6.

18. Haidar SG, Kumar D, Bassi RS, Deshmukh SC. Average versus maximum grip strength: which is more consistent? J Hand Surg $\mathrm{Br}$ 2004;29:82-4. [CrossRef]

19. Petersen P, Petrick M, Connor H, Conklin D. Grip strength and hand dominance: challenging the 10\% rule. Am J Occup Ther. 1989;43:444-7.

20. Armstrong CA, Oldham JA. A comparison of dominant and non-dominant hand strengths. J Hand Surg Br 1999;24:421-5. [CrossRef]

21. Ring D. Displaced, unstable fractures of the radial head: fixation vs. replacement--what is the evidence? Injury 2008;39:1329-37. [CrossRef]

22. Dou Q, Yin Z, Sun L, Feng X. Prosthesis replacement in Mason III radial head fractures: A meta-analysis. Orthop Traumatol Surg Res 2015;101:729-34. [CrossRef]

23. Iftimie PP, Calmet Garcia J, de Loyola Garcia Forcada I, Gonzalez Pedrouzo JE,Giné Gomà J. Resection arthroplasty for radial head fractures: Long-term follow-up.J Shoulder Elbow Surg. 2011;20:45-50. [CrossRef]

24. Swanson AB, Jaeger SH, La Rochelle D. Comminuted fractures of the radial head. The role of silicone-implant replacement arthroplasty. J Bone Joint Surg Am 1981;63:1039-49. [CrossRef]

25. Fuchs S, Chylarecki C. Do functional deficits result from radial head resection? J Shoulder Elbow Surg 1999;8:247-51. [CrossRef]

26. Herbertsson P, Josefsson PO, Hasserius R, Besjakov J, Nyqvist F, Karlsson MK. Fractures of the radial head and neck treated with radial head excision. J Bone Joint Surg Am 2004;86-A:1925-30. [CrossRef]

27. Doornberg JN, Parisien R, van Duijn PJ, Ring D. Radial head arthroplasty with a modular metal spacer to treat acute traumatic elbow instability. J Bone Joint Surg Am 2007;89:1075-80. [CrossRef]

28. Flinkkilä T, Kaisto T, Sirniö K, Hyvönen P, Leppilahti J. Short- to midterm results of metallic press-fit radial head arthroplasty in unstable injuries of the elbow. J Bone Joint Surg Br 2012;94:805-10. [CrossRef]

29. Nicolay CW, Walker AL. Grip strength and endurance: Influences of anthropometric variation, hand dominance, and gender. Int J Ind Ergon. 2005;35:605-18. [CrossRef]

\section{ORİJINAL ÇALIŞMA - ÖZET}

\section{Mason tip III parçalı radius başı kırıklarında rezeksiyon ve protez uygulamalarının fonksiyonel sonuçlarının karşılaştırılması \\ Dr. Mehmet Can Ünlü, ${ }^{1}$ Dr. Mehmet Fatih Güven, ${ }^{1}$ Dr. Lercan Arslan, ${ }^{1}$ Dr. Önder Aydıngöz, ${ }^{1}$ Dr. Mustafa Gökhan Bilgili, ${ }^{2}$ Dr. Alkan Bayrak, ${ }^{2}$ Dr. Muharrem Babacan, ${ }^{1}$ Dr. Gökhan Kaynak, ${ }^{1}$ Dr. Hüseyin Botanlıoğlu'}

'İstanbul Üniversitesi Cerrahpaşa Tıp Fakültesi, Ortopedi ve Tavmatoloji Anabilim Dalı, İstanbul

${ }^{2}$ Bakırköy Dr. Sadi Konuk Eğitim ve Araştırma Hastanesi, Ortopedi ve Travmatoloji Kliniği, İstanbul

AMAÇ: Radius başı ön kol rotasyonel stabilitesi ve dirsek valgus stresine dayanma açısından önemlidir. Radius başı erişkinlerdeki en sık dirsek kırığıdır. Kırığın derecesine göre farklı tedavi yöntemleri tanımlanmıştır. Bununla birlikte, tip III kırıkların tedavisi tartışmalıdır. Bu çalısmanın amacı ileri derecede parçalı Mason tip III radius başı kıııklarının baş rezeksiyonu veya protez ile tedavi sonuçlarının araştııılmasıdır.

GEREÇ VE YÖNTEM: Radius başı rezeksiyonu $(n=7)$ veya radius başı protezi $(n=7)$ ile tedavi edilmiş parçalı Mason tip III kırığı çok merkezli ve geriye dönük olarak değerlendirildi. Klinik sonuçları değerlendirmede DASH (Disabilities of the Arm, Shoulder and Hand) ve Mayo dirsek-el bileği skorları kullanıldı. Kavrama kuvvetini değerlendirmede hidrolik el dinomometresi kullanıldı; kavrama kuvveti her iki taraf ekstremite için üçer kez tekrarlanıp ortalaması alındı. Kavrama kuvveti sağlam tarafa göre yüzde olarak hesaplandı.

BULGULAR: Rezeksiyon ve protez yapılan hastalarda ortalama fonksiyonel sonuçlar sırası ile DASH skoru için 25.8 ve 17.2; Mayo dirsek skoru için 74 ve 84. I; Mayo el bileği skoru için 84 ve 92.5 bulundu. Maksimum kavrama kuvvetleri ise rezeksiyon grubu için \% 48.8 , protez grubu için ise \%77.8 oldu. Ortalama eklem hareket açıklğı rezeksiyon ve protez yapılan gruplarda sırası ile fleksiyon, $112.14^{\circ}$ ve $104.29^{\circ}$; ekstansiyon $-10.00^{\circ}$ ve $-25.00^{\circ}$; pronasyon, $70.00^{\circ}$ ve $47.86^{\circ}$; supinasyon, $70.00^{\circ}$ ve $52.14^{\circ}$ bulundu.

TARTIŞMA: Radius başı rezeksiyonu yapılan hastalarda eklem hareket açıklığı kısıtlanmış bununla beraber fonksiyonel sonuçlar ve kavrama kuvveti radius protezi ile tedavi edilen hastalarda daha iyi olmuştur. Bu sonuçlar ileri derecede parçalı Mason tip III radius başı kırıklarının tedavisinde radius başı protezi uygulamasının hasta memnuniyeti ve fonksiyonel sonuçlar açısından rezeksiyona göre daha iyi olduğunu desteklemektedir. Anahtar sözcükler: Artroplasti; kırı; protez; radius başı; rezeksiyon.

Ulus Travma Acil Cerrahi Derg 2018;24(4):359-363 doi: 10.5505/tjtes.2017.97682 